Internist 2012 ·53:1151-1156

DOI 10.1007/s00108-011-2990-5

Online publiziert: 22. September 2012

(c) Springer-Verlag 2012

Schwerpunktherausgeber

M. Battegay, Basel

J.K. Rockstroh, Basel

Die Fortschritte in der HIV-Medizin von den ersten klinischen Beschreibungen in den USA (1981) über die Entdeckung des HI-Virus als ursächlicher Erreger (1983) bis hin zur effektiven antiretroviralen Kombinationstherapie (CART, 1996) sind einmalig in der Medizingeschichte. Die initiale Hoffnung auf eine Heilung durch die Elimination des Virus war zu optimistisch. Jedoch kann unter einer CART von einer beinahe normalen Lebenserwartung ausgegangen werden $[1,2$, $3,4,5,6,7,8,9]$.

Voraussetzung für die drastische Senkung der Morbidität und Mortalität ist die lebenslange Weiterführung der cART mit hoher Therapieadhärenz - eine große Herausforderung für Patienten und für die behandelnden Ärzte [10, 11]. Wichtige Faktoren für eine weiterhin bestehende erhöhte Morbidität und Mortalität HIV-infizierter Menschen sind die späte Diagnosestellung und/oder Therapieeinleitung [12] sowie Komorbiditäten, insbesondere Koinfektionen mit Hepatitis B oder $\mathrm{C}$ und aktiver i.v.-Drogenkonsum $[13,14,15,16,17,18]$. Die Alterung der Patienten, die mit einer Zunahme an kardiovaskulären Erkrankungen und Tumoren einhergeht, beeinflusst die Betreuung und Prognose von HIV-Patienten bereits heute stark, in der Zukunft wird ihre Bedeutung aber noch steigen [19]. Weiterhin sind mögliche Langzeittoxizitäten als Folge einer mehrere Jahrzehnte dauernden cART zum jetzigen Zeitpunkt noch nicht vollständig absehbar [20, 21, 22, 23].

M. Stöckle · L. Elzi · J.K. Rockstroh · M. Battegay

Klinik für Infektiologie und Spitalhygiene, Universitätsspital Basel

\title{
Morbidität und Mortalität der HIV-Infektion
}

\section{Prognose der HIV-Infektion}

Die Inzidenz AIDS-definierender Erkrankungen hat sich durch die cART auf ein Zehntel reduziert [1, 2, 24, 25, 26, 27, 28], gewisse Erkrankungen durch opportunistische Infektionen wie die Zytomegalovirusretinitis und die progressive multifokale Leukoenzephalopathie, die hauptsächlich mit einer schweren Immundefizienz assoziiert sind, sind selten geworden $[29,30]$. Steigt die CD4-Zellzahl an und verbessert sich die zelluläre Immunabwehr, können bestimmte AIDS-Erkrankungen wie das Kaposi-Sarkom und die progressive multifokale Leukoenzephalopathie sogar ohne spezifische Therapie ausheilen.

Die Mortalitätsraten HIV-infizierter Menschen konnten durch die cART ebenfalls erheblich und kontinuierlich reduziert werden (• Tab. 1). Die HIV-assoziierte Mortalität fiel von 42,7 Todesfällen/ 1000 Patientenjahre vor 1996 auf 16,9 Todesfälle/1000 Patientenjahre im Zeitraum von 1999-2000 und auf 9,6 Todesfälle/ 1000 Patientenjahre in der Spanne von 2007-2008 [31, 32]. In einer Studie der Antiretroviral Therapy Cohort Collaboration (ART-CC), einem internationalen Zusammenschluss großer Kohorten, stieg die Lebenserwartung eines 20-jährigen HIV-infizierten Patienten zwischen 19961999 und 2003-2005 durch die cART von 36,1 auf 49,4 Jahre an [1].

In der Concerted Action on Seroconversion to AIDS and Death in Europe (CASCADE) Collaboration ähnelte die Mortalität HIV-infizierter Menschen in den ersten 5 Jahren nach Infektion der Mortalität in der Normalbevölkerung. Eine Ausnahme bildeten Patien- ten, die sich über i.v.-Drogenkonsum infiziert hatten [32]. Dieser Rückgang der Gesamtsterblichkeit HIV-infizierter Menschen beruht nicht nur auf der Prävention AIDS-definierender Erkrankungen, sondern auch auf der Abnahme nicht-HIVassoziierter Krankheiten und Todesfälle [33].

\section{》) Die Mortalität HIV-infizierter Menschen nähert sich der eines nichtinfizierten an}

Viele der schwerwiegenden, lebensbedrohlichen Ereignisse, die heute bei HIVPatienten unter cART auftreten, sind weder cART- noch AIDS-assoziiert, sondern hepatisch oder kardiovaskulär bedingt. In der Schweizerischen HIV-Kohortenstudie stirbt heutzutage "nur" noch jeder sechste Patient an HIV/AIDS, dies schließt schwer drogenabhängige Patienten mit ein, die vermehrt eine ungenügende Adhärenz aufweisen [34]. Die häufigsten Todesursachen in dieser Arbeit waren nicht-HIV-assoziierte Tumorerkrankungen (19\%), insbesondere das hepatozelluläre Karzinom, AIDS-Erkrankungen (16\%), Hepatopathien (15\%), bakterielle Infektionen (9\%) und kardiovaskuläre Krankheiten (8\%; - Tab. 2).

Morbidität und Mortalität lassen sich auch dann signifikant senken, wenn der virologische Therapieerfolg nicht vollständig ist, d. h., wenn die Viruslast nicht unter die Nachweisgrenze fällt, die CD4Zellzahl sich aber erholt [35, 36, 37, 38]. Eine Studie zeigte, dass bei Patienten, die trotz vollständiger Virussuppression keinen CD4-Anstieg auf 200 Zellen/ $\mu$ l erreichten, das Risiko für opportunistische 


\section{Schwerpunkt}

\begin{tabular}{|c|c|c|c|c|}
\hline Jahr & Studie & Design & Vergleich & Mortalitätsreduktion \\
\hline 1996 & Delta [51] & Randomisierte Studie & AZT vs. duale ART & $33 \%$ \\
\hline 1996 & $\begin{array}{l}\text { AIDS Clinical Trials Group (ACTG) } 175 \\
\text { [52] }\end{array}$ & Randomisierte Studie & AZT vs. duale ART & $49 \%$ \\
\hline 1997 & $\begin{array}{l}\text { AIDS Clinical Trials Group (ACTG) } \\
320 \text { [7] }\end{array}$ & Randomisierte Studie & Duale ART vs. cART & $57 \%$ \\
\hline 1997 & Swiss HIV Cohort Study (SHCS; [8]) & Beobachtungsstudie & Keine cART vs. CART & $65 \%$ \\
\hline 1998 & HIV Outpatient Study (HOPS; [24]) & Beobachtungsstudie & Keine cART vs. CART & $88,3 \%$ \\
\hline 2003 & EuroSIDA [25] & Beobachtungsstudie & $\begin{array}{l}\text { CART 1996/1997 vs. CART } \\
\text { 1998-2002 }\end{array}$ & $66 \%$ \\
\hline 2005 & Swiss HIV Cohort Study (SHCS; [53]) & Beobachtungsstudie & Keine cART vs. cART & $86 \%$ \\
\hline 2007 & Danish Cohort [54] & Beobachtungsstudie & $\begin{array}{l}\text { HIV-Infizierte vs. Nicht- } \\
\text { HIV-Infizierte }\end{array}$ & Medianes Überleben >35 Jahre \\
\hline 2008 & $\begin{array}{l}\text { Antiretroviral Therapy Cohort Colla- } \\
\text { boration (ART-CC; [1]) }\end{array}$ & Beobachtungsstudie & cART vs. keine Therapie & Weitere 43 Jahre Lebenserwartung \\
\hline 2012 & $\begin{array}{l}\text { Collaboration of Observational HIV } \\
\text { Epidemiological Research Europe } \\
\text { (COHERE; [9]) }\end{array}$ & Beobachtungsstudie & $\begin{array}{l}\text { CART vs. allgemeine Be- } \\
\text { völkerung }\end{array}$ & $\begin{array}{l}\text { Ähnliche Lebenserwartung wie Allgemeinbe- } \\
\text { völkerung, außer bei i.v.-Drogenkonsum }\end{array}$ \\
\hline
\end{tabular}

ART Antiretrovirale Therapie; AZT Zidovudin; cART kombinierte antiretrovirale Therapie, auch HAART "highly active antiretroviral therapy" genannt (zunehmend alternativ gebrauchter Ausdruck).

Tab. 2 Risiko eines 35-jährigen Patienten, in den kommenden 6 Monaten an AIDS zu erkranken, in Abhängigkeit von der CD4-Zellzahl und der Viruslast. (Modifiziert nach [44])

\begin{tabular}{|c|c|c|c|c|}
\hline \multirow{2}{*}{$\begin{array}{l}\text { Viruslast (Ko- } \\
\text { pien/ml) }\end{array}$} & \multicolumn{4}{|c|}{ CD4-Zellzahl (Zellen/ $\mu$ I) } \\
\hline & 50 & 100 & 150 & 200 \\
\hline 3000 & $8,5 \%$ & $4,7 \%$ & $3,0 \%$ & $2,0 \%$ \\
\hline 10.000 & $12,1 \%$ & $6,7 \%$ & $4,3 \%$ & $2,9 \%$ \\
\hline 30.000 & $16,6 \%$ & $9,3 \%$ & $5,9 \%$ & $4,0 \%$ \\
\hline 100.000 & $23,1 \%$ & $13,2 \%$ & $8,5 \%$ & $5,8 \%$ \\
\hline 300.000 & $30,8 \%$ & $18,0 \%$ & $11,7 \%$ & $8,0 \%$ \\
\hline
\end{tabular}

Infektionen deutlich verringert war [39]. Diese Daten wurden jedoch in der Collaboration-of-Observational-HIV-Epidemiological-Research-Europe(COHERE)Studie, in der an Patienten mit vollständig supprimierter Viruslast unter cART das Risiko für AIDS oder Tod untersucht wurde, nicht gänzlich bestätigt [40].

Aufgrund der verbesserten Prognose der HIV-Infektion sind Patienten, nachdem sie sich von einer AIDS-definierenden Erkrankung erholt haben, häufig wieder arbeitsfähig. Die zunehmende Produktivität HIV-infizierter Menschen kann langfristig die erheblichen sozioökonomischen Kosten einer lebenslangen cART ausgleichen [41].

\section{Späte Diagnosestellung}

Jeder dritte bis vierte HIV-infizierte $\mathrm{Pa}$ tient stellt sich erst beim Arzt vor, wenn die CD4-Zellzahl bereits die Schwelle von 200 Zellen/ $\mu$ l unterschritten hat und/oder eine AIDS-definierende Erkrankung vorliegt $[12,39,42,43]$. Bei 10\% der Patienten liegt die CD4-Zellzahl bereits $<50$ Zellen/ $\mu$ l, wenn die HIV-Infektion diagnostiziert wird [12]. Risikofaktoren für die späte HIV-Diagnose sind [12, 42, 43]:

- ein höheres Lebensalter,

- ein heterosexueller Transmissionsweg und

- eine nichtkaukasische Ethnie.

Einmal in medizinischer Betreuung wird eine cART sehr bald begonnen; je niedriger die CD4-Zellzahl liegt, desto schneller.

Die späte Diagnosestellung führt zu erheblichen Problemen. Zum einem steigen Morbidität und Mortalität deutlich an, je tiefer die CD4-Zellzahl abgesunken ist. So beträgt beispielsweise das Risiko, in den folgenden 6 Monaten an AIDS zu er- kranken bei einer CD4-Zellzahl $<200 / \mu \mathrm{l}$ je nach Alter und Viruslast bereits $2-8 \%$, bei einer CD4-Zellzahl <50 / $\mu \mathrm{l}$ 8,5-30,8\% [44].Zum anderen ergeben sich aufgrund von opportunistischen Infektionen therapeutische Herausforderungen, die eine intensive Betreuung notwendig machen. Die simultane Behandlung einer opportunistischen Infektion führt häufig zu additiven Nebenwirkungen und Toxizitäten [45] sowie zu Medikamenteninteraktionen [46].

\section{》) Nach später Diagnosestellung gestaltet sich der Beginn der antiretroviralen Therapie schwieriger}

Problematisch ist bei der späten Präsentation darüber hinaus, dass sich der Beginn einer CART schwieriger gestaltet. Erholt sich das Immunsystem rasch, kann ein Immunrekonstitutionssyndrom auftreten, im Rahmen dessen sich präexistente, subklinische Infektionen in den ersten Wochen nach Einleitung der cART manifestieren können. Ein Immunrekonstitutionssyndrom liegt auch vor, wenn es bei gleichzeitiger Behandlung einer opportunistischen Infektion zu einer erheblichen Entzündungsreaktion kommt, die paradoxerweise zu einer vorübergehenden klinischen Verschlechterung führt $[47,48]$. 
Hier steht eine Anzeige.

黛 Springer 
Ein weiteres Problem ist der langsamere und häufig inkomplette Anstieg der CD4-Zellen trotz vollständiger Virussuppression, je tiefer die CD4-Zellzahl zu Beginn der cART liegt $[37,38]$. Die negativen Auswirkungen eines späten Therapiebeginns können lang wahrnehmbar bleiben. So war bei etwa $25 \%$ der Patienten, die mit niedrigen CD4-Zellzahlen eine cART begannen, auch bei guter Virussuppression nach 5-10 Jahren noch immer keine Normalisierung auf 500 CD4Zellen/ $\mu \mathrm{l}$ zu beobachten $[27,49,50]$.

Es gilt $\mathrm{zu}$ betonen, dass die Langzeitprognose dieser Patienten meist exzellent ist, selbst wenn die cART bei einer CD4Zellzahl $<50$ Zellen/ $\mu$ l eingeleitet wird. Gerade ein Anstieg der CD4-Zellzahl in der ersten Phase von $<50$ auf $>50$ Zellen/ $\mu \mathrm{l}$ verbessert die Prognose bereits innerhalb der ersten 6 Monate hochsignifikant $[2,44]$. Daher sind auch die intensivmedizinische Betreuung und Therapie essenziell und klar indiziert, um die Sterblichkeit in den ersten 3-6 Monaten zu reduzieren.

\section{Fazit für die Praxis}

- Die direkt durch AIDS bedingte Morbidität und Mortalität ist dank der hochwirksamen cART drastisch gesunken.

- Die frühzeitige Diagnose der HIV-Infektion ist daher essenziell.

- Späte Präsentationen können vermieden werden, wenn Empfehlungen zum HIV-Test stärker berücksichtigt werden und der Test vermehrt routinemäßig durchgeführt wird, insbesondere bei klinischen Manifestationen, die auf eine HIV-Infektion hinweisen können.

- In zukünftigen Studien gilt es zu untersuchen, ob ein vorzeitiges Altern, das eine erhöhte Morbidität und Sterblichkeit bedingt, auf die HIV-Infektion per se oder auf Komorbiditäten zurückzuführen ist.

Internist 2012 ·53:1151-1156 DOI 10.1007/s00108-011-2990-5

(c) Springer-Verlag 2012

\section{Stöckle · L. Elzi · J.K. Rockstroh · M. Battegay}

\section{Morbidität und Mortalität der HIV-Infektion}

\section{Zusammenfassung}

Morbidität und Mortalität von HIV-infizierten Menschen haben seit 1996 aufgrund der antiretroviralen Kombinationstherapie (CART) dramatisch abgenommen. Die HIV-Infektion wurde somit zu einer chronischen, ambulant behandelbaren und meist asymptomatischen Krankheit mit praktisch normaler Lebenserwartung. Ein Hauptgrund der verbleibenden Morbidität und Sterblichkeit ist, dass die HIV-Infektion in etwa $20 \%$ der Fälle spät diagnostiziert bzw. therapiert wird. Oft liegt zu diesem Zeitpunkt die CD4-Zellzahl bereits unter der Schwelle von 200 Zellen/ $\mu$ l und/ oder AIDS-definierende Krankheiten haben sich manifestiert. Weitere Gründe für die ver- bleibende Morbidität und Mortalität sind Komorbiditäten, insbesondere die Koinfektion mit einer viralen Hepatitis und Tumoren bei älteren Patienten. Durch die verbesserte Prognose nimmt das Alter HIV-infizierter Menschen zu. Dies bedeutet aufgrund von Komorbiditäten und sozioökonomischen Kosten eine erhebliche Herausforderung für die Zukunft.

\section{Schlüsselwörter}

HIV · „Acquired immunodeficiency syndrome" · HIV-Morbidität · HIV-Mortalität · Komorbidität · Antiretrovirale Kombinationstherapie (CART)

\section{Morbidity and mortality in HIV infection}

\section{Abstract}

Combination antiretroviral therapy (CART) has dramatically improved the prognosis of HIV-infected individuals, with a close to a normal life expectancy in a significant proportion of treated individuals. Upon start of CART, HIV-induced immune deficiency can be prevented or, if already present, reconstituted. Remaining morbidity and mortality is partly due to the late diagnosis of HIV infection or late presentation of patients, when CD4-T-cells have already fallen below 200 cells/ $\mu \mathrm{l}$ and/or AIDS-defining conditions have manifested. Further reasons for remaining morbidity and mortality are related to comorbidities such as viral hepatitis and tumors, particularly in older patients. As HIV-infected patients become older, increasing co-morbidities and socio-economic costs may become a challenge in the future.

\section{Keywords}

HIV - Acquired immunodeficiency syndrome . HIV morbidity · HIV mortality · Comorbidity . Combination antiretroviral therapy (CART)

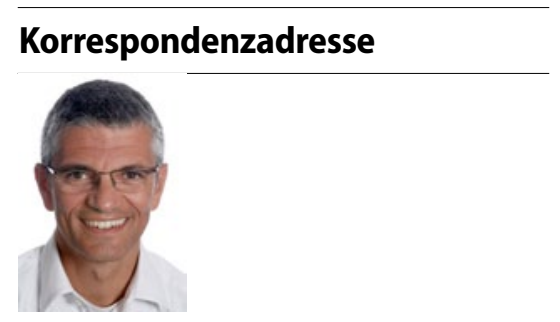

Prof. Dr. M. Battegay

Klinik für Infektiologie und Spitalhygiene, Universitätsspital Basel

Petersgraben 4, 4031 Basel

Schweiz

mbattegay@uhbs.ch

Interessenkonflikt. Der korrespondierende Autor gibt für sich und seine Koautoren an, dass kein Interessenkonflikt besteht.

\section{Literatur}

1. Antiretroviral Therapy Cohort Collaboration (2008) Life expectancy of individuals on combination antiretroviral therapy in high-income countries: a collaborative analysis of 14 cohort studies. Lancet 372:293-299

2. Egger M et al (2002) Prognosis of HIV-1-infected patients starting highly active antiretroviral therapy: a collaborative analysis of prospective studies. Lancet 360:119-129

3. Ledergerber B et al (1999) AIDS-related opportunistic illnesses occurring after initiation of potent antiretroviral therapy: the Swiss HIV Cohort Study. JAMA 282:2220-2226

4. Ledergerber B et al (1999) Clinical progression and virological failure on highly active antiretroviral therapy in HIV-1 patients: a prospective cohort study. Swiss HIV Cohort Study. Lancet 353:863868

5. Ledergerber B, Egger M, Telenti A (2000) AIDS-related opportunistic illness and potent antiretroviral therapy. JAMA 283:2653-2654 
Hier steht eine Anzeige.

黛 Springer 
6. May M et al (2007) Prognosis of HIV-1-infected patients up to 5 years after initiation of HAART: collaborative analysis of prospective studies. AIDS 21:1185-1197

7. Hammer SM et al (1997) A controlled trial of two nucleoside analogues plus indinavir in persons with human immunodeficiency virus infection and CD4 cell counts of 200 per cubic millimeter or less. AIDS Clinical Trials Group 320 Study Team. N Engl J Med 337:725-733

8. Egger M et al (1997) Impact of new antiretroviral combination therapies in HIV infected patients in Switzerland: prospective multicentre study. Swiss HIV Cohort Study. BMJ 315:1194-1199

9. Collaboration of Observational HIV Epidemiological Research Europe (COHERE) in EuroCoord et al (2012) All-cause mortality in treated HIV-infected adults with $\mathrm{CD} 4 \geq 500 / \mathrm{mm}^{3}$ compared with the general population: evidence from a large European observational cohort collaboration. Int J Epidemiol 41:433-445

10. Strategies for Management of Antiretroviral Therapy (SMART) Study Group et al (2006) CD4+ countguided interruption of antiretroviral treatment. N Engl J Med 355:2283-2296

11. Kaufmann GR et al (2011) Interruptions of CART limits CD4 T-cell recovery and increases the risk for opportunistic complications and death. AIDS 25:441-451

12. Wolbers M et al (2008) Delayed diagnosis of HIV infection and late initiation of antiretroviral therapy in the Swiss HIV Cohort Study. HIV Med 9:397405

13. Weber R et al (2006) Liver-related deaths in persons infected with the human immunodeficiency virus: the D:A:D study. Arch Intern Med 166:16321641

14. Data Collection on Adverse Events of Anti-HIV drugs (D:A:D) Study Group et al (2010) Factors associated with specific causes of death amongst HIV-positive individuals in the D:A:D Study. AIDS 24:1537-1548

15. Murray M et al (2012) The effect of injecting drug use history on disease progression and death among HIV-positive individuals initiating combination antiretroviral therapy: collaborative cohort analysis. HIV Med 13:89-97

16. Study Group on Death Rates at High CD4 Count in Antiretroviral Naive Patients et al (2010) Death rates in HIV-positive antiretroviral-naive patients with CD4 count greater than 350 cells per $\mu$ in Europe and North America: a pooled cohort observational study. Lancet 376:340-345

17. Monforte A et al (2008) HIV-induced immunodeficiency and mortality from AIDS-defining and nonAIDS-defining malignancies. AIDS 22:2143-2153

18. Lacombe K, Rockstroh J (2012) HIV and viral hepatitis coinfections: advances and challenges. Gut 61(Suppl 1):i47-58

19. Hasse B et al (2011) Morbidity and aging in HIV-infected persons: the Swiss HIV cohort study. Clin Infect Dis 53:1130-1139

20. Fux CA et al (2007) Tenofovir use is associated with a reduction in calculated glomerular filtration rates in the Swiss HIV Cohort Study. Antivir Ther 12:1165-1173

21. Grinspoon S, Carr A (2005) Cardiovascular risk and body-fat abnormalities in HIV-infected adults. N Engl J Med 352:48-62

22. Kowalska JD et al (2012) Long-term exposure to combination antiretroviral therapy and risk of death from specific causes: no evidence for any previously unidentified increased risk due to antiretroviral therapy. AIDS 26:315-323
23. Ledergerber B et al (2007) Factors associated with the incidence of type 2 diabetes mellitus in HIV-infected participants in the Swiss HIV Cohort Study. Clin Infect Dis 45:111-119

24. Palella FJ Jr et al (1998) Declining morbidity and mortality among patients with advanced human immunodeficiency virus infection. HIV Outpatient Study Investigators. N Engl J Med 338:853-860

25. Mocroft A et al (2003) Decline in the AIDS and death rates in the EuroSIDA study: an observational study. Lancet 362:22-29

26. Mocroft A et al (2010) Serious fatal and nonfatal non-AIDS-defining illnesses in Europe. J Acquir Immune Defic Syndr 55:262-270

27. May M et al (2007) Prognosis of HIV-1-infected patients up to 5 years after initiation of HAART: collaborative analysis of prospective studies. AIDS 21:1185-1197

28. d'Arminio Monforte A et al (2005) The changing incidence of AIDS events in patients receiving highly active antiretroviral therapy. Arch Intern Med 165:416-423

29. Khanna N et al (2009) Incidence and outcome of progressive multifocal leukoencephalopathy over 20 years of the Swiss HIV Cohort Study. Clin Infect Dis 48:1459-1466

30. Sugar EA et al (2012) Incidence of cytomegalovirus retinitis in the era of highly active antiretroviral therapy. Am J Ophthalmol 153:1016-1024.e5

31. Porter K et al (2008) Changes in outcome of persons initiating highly active antiretroviral therapy at a CD4 count less than 50 cells $/ \mathrm{mm}^{3}$. J Acquir Immune Defic Syndr 47:202-205

32. Bhaskaran K et al (2008) Changes in the risk of death after HIV seroconversion compared with mortality in the general population. JAMA 300:51-59

33. Deeks SG, Phillips AN (2009) HIV infection, antiretroviral treatment, ageing, and non-AIDS related morbidity. BMJ 338:a3172

34. Ruppik M, Ledergerber $B$, Rickenbach $M$ et al (2011) Changing patterns of causes of death: the Swiss HIV Cohort Study 2005-2009. CROI, Poster 156

35. Ledergerber B et al (2004) Predictors of trend in CD4-positive T-cell count and mortality among HIV-1-infected individuals with virological failure to all three antiretroviral-drug classes. Lancet 364:51-62

36. Mocroft $A$ et al (2010) Estimated average annual rate of change of CD4(+) T-cell counts in patients on combination antiretroviral therapy. Antivir Ther 15:563-570

37. Kaufmann GR et al (2005) Characteristics, determinants, and clinical relevance of CD4 T cell recovery to $<500$ cells/microL in HIV type 1-infected individuals receiving potent antiretroviral therapy. Clin Infect Dis 41:361-372

38. Kaufmann GR et al (2003) CD4 T-lymphocyte recovery in individuals with advanced HIV-1 infection receiving potent antiretroviral therapy for 4 years: the Swiss HIV Cohort Study. Arch Intern Med 163:2187-2195

39. Zoufaly A et al (2011) Clinical outcome of HIV-infected patients with discordant virological and immunological response to antiretroviral therapy. J Infect Dis 203:364-371

40. Opportunistic Infections Project Team of the Collaboration of Observational HIV Epidemiological Research in Europe (COHERE) in EuroCoord (2012) CD4 cell count and the risk of AIDS or death in HIVinfected adults on combination antiretroviral therapy with a suppressed viral load: a longitudinal cohort study from COHERE. PLoS Med 9:e1001194
41. Sendi P et al (2004) Productivity costs and determinants of productivity in HIV-infected patients. Clin Ther 26:791-800

42. Waters L, Sabin CA (2011) Late HIV presentation: epidemiology, clinical implications and management. Expert Rev Anti Infect Ther 9:877-889

43. Battegay M et al (2007) Late presentation of HIVinfected individuals. Antivir Ther 12:841-851

44. Phillips A, Pezzotti P, CASCADE Collaboration (2004) Short-term risk of AIDS according to current CD4 cell count and viral load in antiretroviral drugnaive individuals and those treated in the monotherapy era. AIDS 18:51-58

45. Elzi L et al (2010) Treatment modification in human immunodeficiency virus-infected individuals starting combination antiretroviral therapy between 2005 and 2008. Arch Intern Med 170:57-65

46. Marzolini C et al (2010) Prevalence of comedications and effect of potential drug-drug interactions in the Swiss HIV Cohort Study. Antivir Ther 15:413423

47. Battegay M et al (2006) Immunological recovery and antiretroviral therapy in HIV-1 infection. Lancet Infect Dis 6:280-287

48. Hirsch HH et al (2004) Immune reconstitution in HIV-infected patients. Clin Infect Dis 38:11591166

49. Kelley CF et al (2009) Incomplete peripheral CD4+ cell count restoration in HIV-infected patients receiving long-term antiretroviral treatment. Clin Infect Dis 48:787-794

50. Antiretroviral Therapy Cohort Collaboration (2007) Importance of baseline prognostic factors with increasing time since initiation of highly active antiretroviral therapy: collaborative analysis of cohorts of HIV-1-infected patients. J Acquir Immune Defic Syndr 46:607-615

51. Delta Coordinating Committee (1996) Delta: a randomised double-blind controlled trial comparing combinations of zidovudine plus didanosine or zalcitabine with zidovudine alone in HIV-infected individuals. Delta Coordinating Committee. Lancet 348:283-291

52. Hammer SM et al (1996) A trial comparing nucleoside monotherapy with combination therapy in HIV-infected adults with CD4 cell counts from 200-500 per cubic millimeter. AIDS Clinical Trials Group Study 175 Study Team. N Engl J Med 335:1081-1090

53. Sterne JA et al (2005) Long-term effectiveness of potent antiretroviral therapy in preventing AIDS and death: a prospective cohort study. Lancet 366:378-384

54. Lohse $\mathrm{N}$ et al (2007) Survival of persons with and without HIV infection in Denmark, 1995-2005. Ann Intern Med 146:87-95 